\title{
RELATIONS BETWEEN ANOMIA AND VALUES OF THE INHABITANTS OF THE BALTIC STATES
}

\author{
Jel̦ena L̦evina \\ Kristīne Mārtinsone \\ Kristiāna Klince \\ Rīga Stradiņš University, Latvia
}

\begin{abstract}
The purpose of this study was to determine the structure of anomia among the inhabitants of the Baltic states and to investigate whether there are relations between different dimensions of anomia and personal values. The secondary data from the European Values Study (EVS, 2008) were used. The sample consisted of the inhabitants of Latvia $(n=1506)$, Lithuania $(n=1500)$, and Estonia $(n=1518)$. For measurement of anomia and values questions from the original questionnaire of the EVS were used. In this study five components of anomia were found, namely, local social distrust, local social isolation, normlessness, global social distrust, and global social isolation. Numerous relations between anomia and values were found. It was found that there are the following common, similar patterns of relations between anomia and values of the inhabitants of Latvia, Lithuania and Estonia: (1) the importance of politics and religion is negatively associated with all dimensions of anomia (with one exception - there is no found the significant relation between the importance of religion and global social distrust in Latvia); (2) the importance of work and family is negatively associated with normlessness; (3) the importance of friends and acquaintances is negatively associated with global social distrust. Estonia was the only country for which it was found that the value of friends and acquaintances was negatively associated with global social isolation and the value of leisure time was negatively associated with local and global social distrust. The value of leisure time was positively associated with local social isolation in Lithuania and with normlessness in Latvia.
\end{abstract}

Keywords: anomie, anomia, normlessness, social isolation, meaninglessness, values.

\section{Introduction}

Present-day Western societies are characterized by constant changes globalization, rapid development of technologies, social and economic processes. Such transitions can cause changes of social norms and values, attitudes, social cohesion at the level of the whole society as well as can influence each its member individually. Rapid social changes cause the emergence of acute social anomie that can lead to socially harmful modes of behavior (in extreme cases suicide or murder), unless effective social regulatory forces are available (Durkheim, 1964 [1893], 1966 [1951]). 
Jeļena L̦evina, Kristīne Mārtinsone, Kristiāna Klince. Relations Between Anomia and Values of the Inhabitants of the Baltic States

According to the Cambridge dictionary of psychology anomie is a term, which describes "a state of alienation from society and a sense of hopelessness engendered by rapid social change and especially a change in values or beliefs" (Matsumoto, 2009, p. 40). Anomie refers to a state of a society in which there is a breakdown of social norms and guidance for the citizens of a society (Durkheim, 1964 [1893]), a lack of "integratedness" of social systems at the macroscopic level (Srole, 1956), a discrepancy between common social goals and the legitimate means to attain those goals (Merton, 1964).

Anomie, which characterizes the state of a society, can lead to anomia. Recently anomia was defined as an individually psychological state, when the person beliefs that there are no social norms, rules and prescriptions, which can regulate his / her own behavior as well as the behavior of other citizens of the society, when the person endures the psychological state of meaninglessness and social isolation (L̦evina, Mārtinsone \& Kamerāde, 2015b).

Most scientists view human values as desirable goals, varying in importance that guide, justify or explain attitudes, norms, opinions and actions (e.g., Rokeach, 1973; Schwartz, 2006). Values are guidelines in human life (Eņgele, 2015).

It is possible to assume that during the period of rapid socially economic, technological, political, cultural changes, when an individual experiences a state of anomia, he / she have to re-evaluate his / her own personal values, to find new principles and meanings of life, and sometimes even to re-consider his / her individual philosophy, which is founded upon the values.

Substantial and / or dynamicaspects of personal value-meaning systems in connection to social, economic, politic, cultural factors have been studied widely both worldwide (e.g. Karvonen et al., 2012; Lan, 2009; Likitapiwat et al., 2015; Maercker et al., 2015; Meral, 2000; Salikhova, 2015; Schwartz \& Bardi, 1997) and in the Baltic states, in particular in Latvia (e.g. Jirgena \& Mārtinsone, 2007; Lūse, 2001; L Levina, Mārtinsone et al., 2015). However, there is the lack of research of the relations between different types of values and different dimensions of anomia, especially in the Baltic states. Perhaps the only study of this issue was conducted in Latvia by Kristiāna Klince (Klince, 2015).

Thus, the purpose of this research is to investigate the structure of anomia in the sample of the inhabitants of the Baltic states and to determine whether there are relations between different dimensions of anomia and personal values.

\section{The concept of anomia}

One of the first scientists who investigated an individual state of anomie or anomia was Leo Srole (Srole, 1956). According to Srole anomia refers to the individual's generalized sense of "self-to-others belongingness"-"self-to-others 
alienation".

Analyzing five components of anomia described by Srole (Srole, 1956), Carter and Carter (Carter \& Carter, 2007) concluded that the individual with anomic characteristics will seem to be disconnected from: a) the larger political norms of society; b) the larger cultural norms of society; c) the larger economic norms of society; d) 'internalized social norms and values'; and e) the main socialization group.

According to Orru (Orru, 1987) Srole's measure of anomia expresses the malintegration or dysfunctional relation of individuals to their social worlds. Really, there is empirical evidence that strong ties to various social groups appeared less likely to succumb to anomie and deviance (Carter \& Carter, 2007).

It is important to emphasize that Srole (Srole, 1956) believed that it is necessary to distinguish between two levels of phenomenon - macro-level or a lack of integratedness of social systems and micro-level or a breakdown of an individual's sense of attachment to society. This leads some researchers to criticize his theory because of not clearly defining the differences between social and individual levels of anomia (Legge et al., 2008).

Later, different components of anomia were studied such as political apathy, the manner of communication with parents and peers, the individual position taken on the question of immigration and the development of derogatory attitudes towards weak groups in society, right through to a general propensity to violence (e.g. Herrmann 2001; Kühnel \& Schmidt 2002; Fuchs 2003; Hüpping 2006; Stolz 2000; Terwey 2000 as mentioned in Legge et al., 2008).

It is evident that anomia has been studied widely. In spite of the fact, that many scientists have investigated an individual state of anomie, in other words, anomia, and described different its dimensions or characteristics, there was no consensus between them. Recently, in order to solve this problem a new integrative multidimensional model of anomia has been developed (Levina \& Martinsone, 2015; Levina, Martinsone \& Kamerade, 2015; L,evina, Mārtinsone \&Kamerāde, 2015b; L,evina, Mārtinsone \& Kamerāde, 2016).

According to this model anomia is a multidimensional construct and includes three main dimensions: normlessness, social isolation and meaninglessness.

Each main dimension of anomia is divided into two sub-dimensions:

- normlessness includes an individual's deviation from prescribed rules or customs andsocial distrust;

- social isolation includes estrangement to others and cultural isolation;

- meaninglessness includes the lack of goal clarity and generalized sense of meaninglessness. 
Jeļena L̦evina, Kristīne Mārtinsone, Kristiāna Klince. Relations Between Anomia and Values of the Inhabitants of the Baltic States

Using this model, a number of studies of anomia have been conducted. For example, in the sample of Latvian inhabitants, three indices and respectively three subscales of anomia, namely, Social Distrust, Social Isolation and Meaninglessness, were constructed (Ļevina, Mārtinsone \& Kamerāde, 2015b). In the same study it was found that there was a significant difference in multidimensional anomia between Latvian inhabitants of different age groups. In another study (Levina, Martinsone \& Kamerade, 2015) it was found that there are relations between anomia and subjective well-being.

In the most recent research (L̦evina, Mārtinsone \& Kamerāde, 2016) which general issue was to investigate whether anomia should be treated and assessed as a unidimensional construct or as a multidimensional one, in all three Baltic states as well as separately in Latvia, Lithuania and Estonia, three dimensions of anomia were found, namely, distrust to government and other social institutions, social isolation and meaninglessness.

Thus, the literature analysis allows to us conclude that anomia should be conceptualized and measured as a multidimensional concept, which includes at least three major dimensions, namely, normlessness, social isolation, and meaninglessness.

\section{The concept of personal values}

Values have beenwidelystudied in the field of psychology. Different theories and models of human values were developed among which the most popular are Allport-Vernon-Lindzey model of value orientations (Allport et al., 1951), Rokeach's theory of values (Rokeach, 1973) and Schwartz's model of basic values (Schwartz, 1992).

Allport, Vernon and Lindzey based their model of value orientations on the seminal work of Eduard Spranger (Spranger, 1928). Values are basic convictions that a person holds about what is and is not important in life, and determine an individual's life philosophy. Allport, Vernon and Lindzey defined six value orientation types: theoretical (discovery of truth, empiricism, intellectualism), economic (usefulness, resourceful, practical affairs), aesthetic (form, beauty, harmony, grace, artistry in life), social (seeking love and acceptance, altruism, sympathy, caring), political (power, influence, leadership) and religious (unity of life, comprehension of life's meaning, holiness) (Allport et al., 1951).

Rokeach defined a value as "an enduring belief that a specific mode of conduct or end-state of existence is personally or socially preferable to an opposite or converse mode of conduct or end-state of existence" (Rokeach, 1973 , p. 5). He has divided values into two types - terminal values (existential goals that a person would like to achieve during his or her lifetime, for example, freedom, family safety, happiness, accomplishment, equality etc.) and 
instrumental values (main principles, behavior modes such as responsibility, courage, creativity, self-control etc.).

Schwartz (Schwartz, 1992) defined values as transsituational goals varying in importance, which serve as guiding principles in the life of a person or group. He describes ten basic values - self-direction (independent thought and action), stimulation (excitement, novelty, and challenge in life), hedonism (pleasure and sensuous gratification for oneself), achievement (personal success), power (social status and prestige, control or dominance), security (safety, harmony, and stability), conformity (restraint of actions, inclinations, and impulses), tradition (respect, commitment, and acceptance of customs) and benevolence (preserving and enhancing the welfare of people around them).

In summary, there are many theoretical value concepts that have also been researched empirically. In this study Allport-Vernon-Lindzey value types are used where values are defined as main life orientations and motivations.

\section{Anomia and personal values}

Though the importance of both anomia and personal values for understanding of individually psychological state, motivations and attitudes of individuals in the modern society, it is evident that little work has been done in order to examine the relations between anomia and values.

In some previous studies researchers investigated relations between a separate certain dimension of anomia and values. For example, Swader (Swader, 2011) explored links between normlessness and value change in the Postcommunist countries.Konty (Konty, 2005) in his research of microanomie investigated links between deviant behaviour and self-enhancing and selftranscending values.

At the same time it is acknowledged that anomia is multidimensional. Examination of the existing literature allows to conclude that relations between multiple dimensions of anomia and different personal values have not been investigated.

\section{The present study}

As mentioned above, the main objective of this study is to investigate whether there arerelations between different dimensions of anomia and personal values of the inhabitants of the Baltic states.

In the current study there are three main research questions:

1. What is the structure of anomia among the inhabitants of the Baltic states?

2. What are the relations between different dimensions of anomia and 
Jel̦ena L̦evina, Kristīne Mārtinsone, Kristiāna Klince. Relations Between Anomia and Values of the Inhabitants of the Baltic States

personal values of the inhabitants of the Baltic states?

3. What are the common, similar patterns and specific patterns of relations between dimensions of anomia and personal values of the inhabitants of Latvia, Lithuania and Estonia?

The additional purpose of this study is using questions and secondary data from the European Values Study (European Values Study (EVS), 2008) to construct subscales, which measure different dimensions of anomia.

\section{Methodology}

In this study in order to investigate whether there arerelations between different dimensions of anomia and personal values of the inhabitants of the Baltic statesthe secondary data from the European Values Study (European Values Study (EVS), 2008) were used. The data were collected in 2008 in many European countries. However, in this research the secondary data only for the Baltic states were used.

\section{Participants}

The sample of the inhabitants of the Baltic states consisted of 4524 participants aged between 18 and 98 years $(M=47.85, S D=18.32) ; 39.3 \%$ of participants were males $(n=1776)$ and $60.7 \%$ were females $(n=2748)$.

The Latvian sample consisted of 1506 participants aged between 18 and 93 years $(M=46.77, S D=18.40) ; 37 \%$ of participants were males $(n=557)$ and $63 \%$ were females $(n=949)$. The Lithuanian sample consisted of 1500 participants aged between 18 and 88 years $(M=46.66, S D=17.89) ; 45.5 \%$ of participants were males $(n=683)$ and $54.5 \%$ were females $(n=817)$. Respectively, the Estonian sample consisted of 1518 participants aged between 18 and 98 years $(M=50.11, S D=18.45) ; 35.3 \%$ of participants were males $(n=536)$ and $64.7 \%$ were females $(n=982)$.

\section{Instruments}

Anomia. For measurement of anomia in this study on the base of the questionnaire of the EVS and the integrative multidimensional model of anomia (Levina \& Martinsone, 2015; Levina, Martinsone, Kamerade, 2015; Levina, Mārtinsone, Kamerāde, 2015b; Luevina, Mārtinsone, Kamerāde, 2016) several indices of anomia and respectively subscales, which measure different dimensions of anomia, were constructed. At the first stage of the construction of the anomia's subscales all original questions of the EVS were analyzed and compared with different dimensions, subdimensions, and signs of anomia. The first item pool consisted of 43 items, however, based on the results of a principal components analysis, the number of items was reduced to 17. Some of the original items of the EVS initially were negatively worded. These items were reversed. 
Values. For research of values of Latvian inhabitants six questions from the EVS were used. A respondent had to evaluate six values - work, family, friends and acquaintances, leisure time, politics and religion, - and to mark how important each value is in his / her life. In the original version of the questionnaire of the EVS the following scale was used: 1 - very important, 2 quite important, 3 - not important, 4 - not at all important. In our study evaluations were reversed. Thus, the higher score meant the more important value.

\section{Results}

\section{Results of the research of the structure of anomia of the inhabitants of the Baltic states and the construction of Anomia subscales}

In order to determine the structure of anomia among the inhabitants of the Baltic states, a principal components analysis with varimax rotation was performed on the responses which were initially selected as referring to different signs of anomia. As a result the number of items was reduced to 17 and a model with five components was chosen.

The principal components analysis revealed a structure of five components, which explained $68.55 \%$ of variance. $\mathrm{KMO}=.80$ and Bartlett test is statistically significant $\chi^{2}(136)=21430.67(p=.000)$. T he component matrix for the fivecomponent solution is shown in Table 1.

Table 1 Results of Principal Component Analysis with varimax rotation for the sample of the inhabitants of the Baltic states

\begin{tabular}{|c|c|c|c|c|c|c|}
\hline \multirow[t]{3}{*}{ Anomia's components and variables } & \multicolumn{6}{|c|}{ Component Loadings } \\
\hline & $C 1$ & $C 1$ & $C 2$ & C3 & C4 & $C 5$ \\
\hline & \multicolumn{3}{|c|}{ before rotation } & \multicolumn{3}{|c|}{ after rotation } \\
\hline \multicolumn{7}{|l|}{ Local social distrust } \\
\hline Q63R. Confidence in government & .61 & .79 & .04 & .04 & .20 & .10 \\
\hline Q63G. Confidence in parliament & .57 & .78 & -.01 & .03 & .20 & .08 \\
\hline Q63Q. Confidence in political parties & .51 & .77 & -.03 & -.04 & .09 & .16 \\
\hline Q63M. Confidence in health care system & .43 & .58 & .04 & .08 & .18 & -.13 \\
\hline Q63C. Confidence in education system & .43 & .46 & .16 & .18 & .17 & -.19 \\
\hline \multicolumn{7}{|l|}{ Local social isolation } \\
\hline $\begin{array}{l}\text { Q84D. Concern with living conditions of } \\
\text { sick and disabled }\end{array}$ & .53 & .04 & .91 & .12 & .03 & .15 \\
\hline $\begin{array}{l}\text { Q84E. Concern with living conditions of } \\
\text { poor children }\end{array}$ & .54 & .05 & .89 & .12 & .07 & .13 \\
\hline $\begin{array}{l}\text { Q84A. Concern with living conditions of } \\
\text { elderly people }\end{array}$ & .50 & .04 & .85 & .09 & .03 & .19 \\
\hline
\end{tabular}


Jel̦ena L̦evina, Kristīne Mārtinsone, Kristiāna Klince. Relations Between Anomia and Values of the Inhabitants of the Baltic States

\begin{tabular}{|c|c|c|c|c|c|c|}
\hline \multicolumn{7}{|l|}{ Normlessness } \\
\hline $\begin{array}{l}\text { Q68M. Justification of paying cash to avoid } \\
\text { taxes }\end{array}$ & .40 & .09 & .06 & .80 & .02 & .09 \\
\hline Q68B. Justification of cheating on tax & .39 & .04 & .07. & .78 & .08 & .07 \\
\hline Q68G. Justification of accepting a bribe & & -.02 & .11 & .75 & .02 & .05 \\
\hline $\begin{array}{l}\text { Q680. Justification of avoiding fare public } \\
\text { transport }\end{array}$ & .32 & .10 & .07 & .75 & -.02 & -.10 \\
\hline \multicolumn{7}{|l|}{ Global social distrust } \\
\hline $\begin{array}{l}\text { Q63L. Confidence in united nations } \\
\text { organisation }\end{array}$ & .61 & .20 & .05 & .04 & .86 & .06 \\
\hline Q63K. Confidence in NATO & .61 & .25 & .05 & .02 & .85 & .03 \\
\hline Q63J. Confidence in European Union & .65 & .31 & .04 & .04 & .79 & .12 \\
\hline \multicolumn{7}{|l|}{ Global social isolation } \\
\hline $\begin{array}{l}\text { Q83F. Concern with living conditions of } \\
\text { humankind }\end{array}$ & .45 & .02 & .24 & .06 & .07 & .90 \\
\hline $\begin{array}{l}\text { Q83E. Concern with living conditions of } \\
\text { europeans }\end{array}$ & .49 & .06 & .23 & .05 & .12 & .89 \\
\hline Eigenvalues & & 2.62 & 2.50 & 2.46 & 2.26 & 1.82 \\
\hline$\%$ of variance & & 15.42 & 14.73 & 14.45 & 13.27 & 10.69 \\
\hline
\end{tabular}

All components had high loadings for items from equivalent anomia dimensions and could be identified as Local social distrust (C1), Local social isolation (C2), Normlessness (C3), Global social distrust (C4), Global social isolation (C5).

Respectively, five scales of anomia were constructed. Descriptive statistics and Cronbach's alpha coefficients for all scales of anomia were computed which are presented in Table 2.

Table 2 Descriptive statistics and reliability indices for Anomia scales in the sample of the inhabitants of the Baltic states

\begin{tabular}{lccccc}
\hline Scale & $\begin{array}{c}\text { Number of } \\
\text { items }\end{array}$ & $\begin{array}{c}\text { Likert } \\
\text { scale }\end{array}$ & $\begin{array}{c}\text { Cronbach's } \\
\boldsymbol{\alpha}\end{array}$ & $\boldsymbol{M}$ & $\boldsymbol{S D}$ \\
\hline Local social distrust & 5 & {$[1-4]$} & .75 & 14.08 & 2.58 \\
Local social isolation & 3 & {$[1-5]$} & .89 & 7.60 & 2.73 \\
Normlessness & 4 & {$[1-10]$} & .78 & 11.07 & 6.99 \\
Global social distrust & 3 & {$[1-4]$} & .85 & 7.53 & 2.16 \\
Global social isolation & 2 & {$[1-5]$} & .90 & 7.39 & 1.88 \\
\hline
\end{tabular}

The coefficients ranged from .75 to .90 , so that it could be said that reliability for all scales was acceptably high (see Table 2). 


\section{Results of the research of relations between dimensions of anomia and values of the inhabitants of the Baltic states}

Results for the Baltic states. To clarify what are the relations between different dimensions of anomia of the inhabitants of the Baltic states and their values the Spearman's correlation analysis was used (Table 3).

Table 3 Descriptive statistics and Spearman's correlation coefficients for measures of anomia and values of Baltic inhabitants

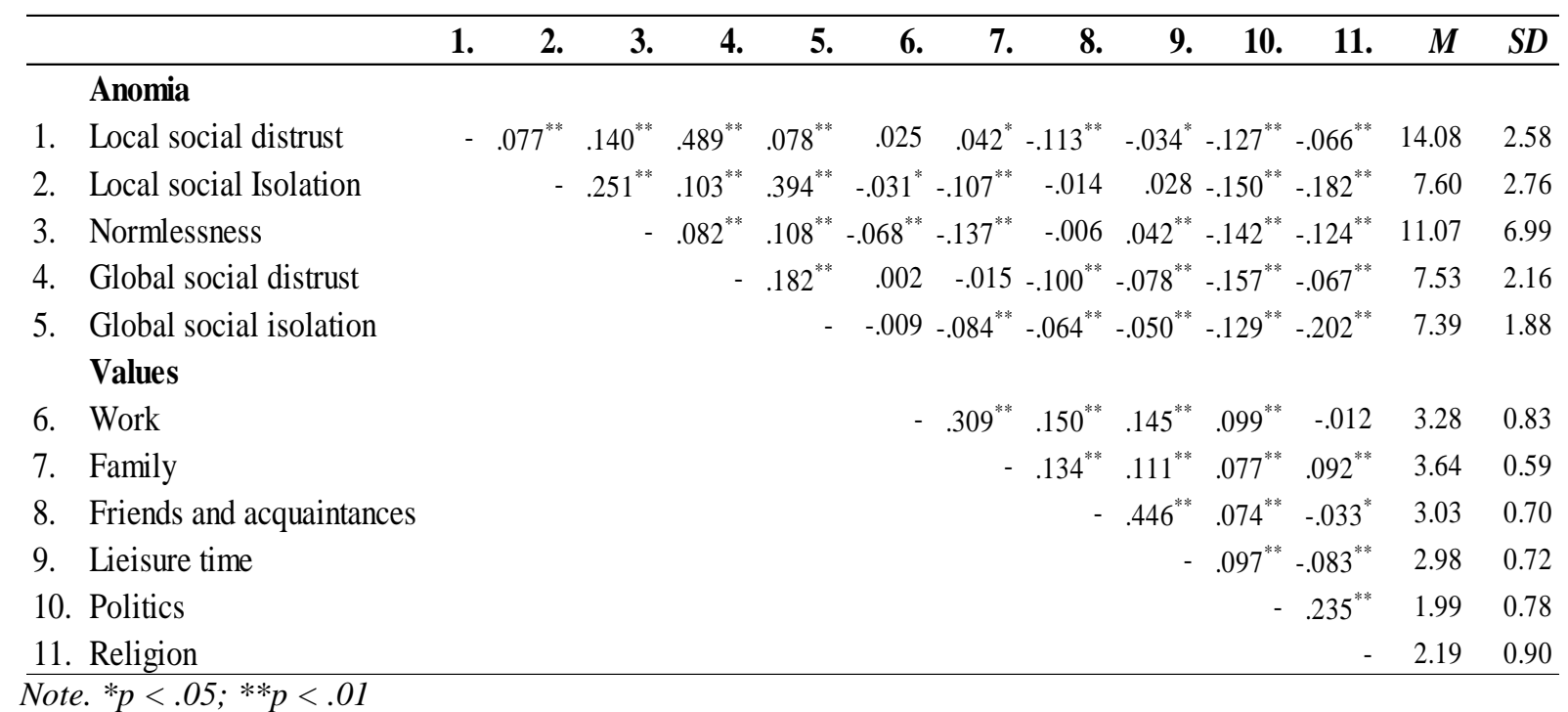

Firstly, it was found that such dimension of anomia as local social distrust was positively associated with value of family $(p<.05)$ and negatively associated with such values as (1) friends and acquaintances $(p<.01),(2)$ leisure time $(p<.05),(3)$ politics $(p<.01)$ and $(4)$ religion $(p<.01)$. Secondly, it was also found that local social isolation was negatively associated with such values as (1) work $(p<.05),(2)$ family $(p<.01)$, (3) politics $(p<.01)$ and (4) religion $(p<.01)$. Correlation analysis showed that normlessness was positively associated with value of leisure time $(p<.01)$ and negatively associated with such values as (1) work $(p<.01)$, (2) family $(p<.01),(3)$ politics $(p<.01)$ and (4) religion $(p<.01)$.

Global social distrust was negatively associated with values of (1) friends and acquaintances $(p<.01),(2)$ leisure time $(p<.01)$, (3) politics $(p<.01)$ and (4) religion $(p<.01)$. At last such dimension of anomia as global social isolation was negatively associated with values of (1) family $(p<.01)$, (2) friends and acquaintances $(p<.01)$, (3) leisure time $(p<.01)$, (4) politics $(p<.01)$ and (5) religion $(p<.01)$. 
Jel̦ena L̦evina, Kristīne Mārtinsone, Kristiāna Klince. Relations Between Anomia and Values of the Inhabitants of the Baltic States

Results for Latvia. At the next stage of our research in order to determine the common, similar patterns and specific patterns of relations between dimensions of anomia and personal values of the inhabitants of Latvia, Lithuania and Estonia the relations between different dimensions of anomia and values were analyzed in the sample of the inhabitants of each from the Baltic states separately. Descriptive statistics and Spearman's correlation coefficients for measures of anomia and values for Latvian inhabitants are presented in Table 4.

Table 4 Descriptive statistics and Spearman's correlation coefficients for measures of anomia and values of Latvian inhabitants

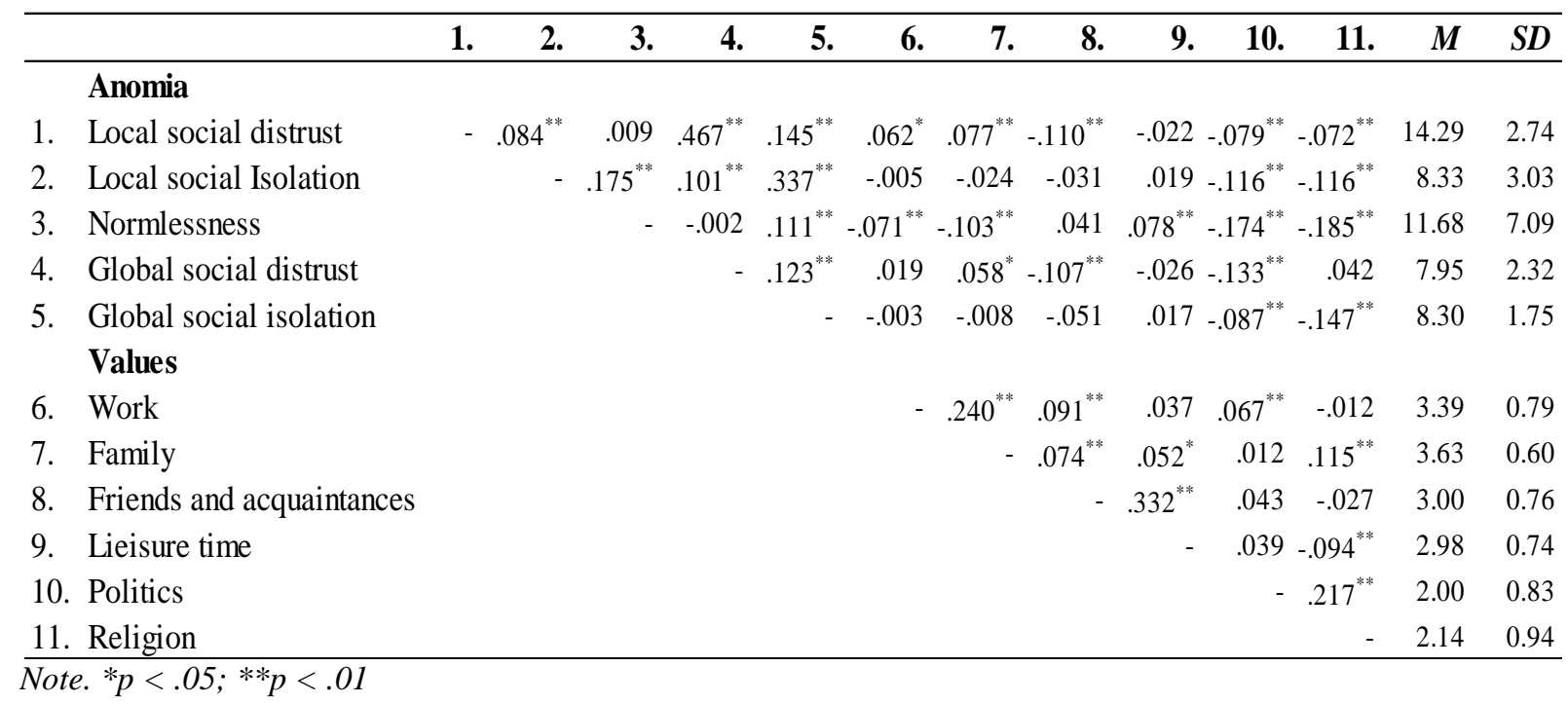

It was found that such dimension of anomia as local social distrust was positively associated with such values as (1) work ( $p<.05)$ and (2) family $(p<.01)$ and negatively associated with such values as (1) friends and acquaintances $(p<.01)$, $(2)$ politics $(p<.01)$ and $(3)$ religion $(p<.01)$. Local social isolation was negatively associated with such values as (1) politics $(p<.01)$ and $(2)$ religion $(p<.01)$. Normlessness was positively associated with value of leisure time $(p<.01)$ and negatively associated with values of $(1)$ work $(p<.01)$, (2) family ( $p<.01)$, (3) politics $(p<.01)$ and (4) religion $(p<.01)$. Global social distrust was positively associated with value of family $(p<.05)$ and negatively associated with values of (1) friends and acquaintances $(p<.01)$ and (2) politics $(p<.01)$. Global social isolation was negatively associated with values of (1) politics $(p<.01)$ and (2) religion $(p<.01)$.

Results for Lithuania. Descriptive statistics and Spearman's correlation coefficients for measures of anomia and values for Lithuanian inhabitants are presented in Table 5. 
It was found that such dimension of anomia as local social distrust was positively associated with such values as (1) work $(p<.01)$ and (2) family $(p<.01)$ and negatively associated with such values as $(1)$ politics $(p<.01)$ and $(2)$ religion $(p<.01)$. Local social isolation was positively associated with such values as (1) friends and acquaintances $(p<.01)$ and (2) leisure time $(p<.01)$ and negatively associated with values of (1) work $(p<.05)$, (2) family $(p<.01)$, (3) politics $(p<.01)$ and (4) religion $(p<.01)$. Normlessness was negatively associated with values of (1) work $(p<.05)$, (2) family $(p<.01)$, (3) politics $(p<.01)$ and $(4)$ religion $(p<.01)$.

Table 5 Descriptive statistics and Spearman's correlation coefficients for measures of anomia and values of Lithuanian inhabitants

\begin{tabular}{|c|c|c|c|c|c|c|c|c|c|c|c|c|c|}
\hline & 1. & 2. & 3. & 4. & 5. & 6. & 7. & 8. & 9. & 10. & 11. & $M$ & $S D$ \\
\hline Anomia & & & & & & & & & & & & & \\
\hline 1. Local social distrust & - & -.002 & $.141^{* *}$ & $.467^{* *}$ & -.035 & $.094^{* *}$ & $.111^{* *}$ & -.030 & .043 & $-.143^{* *}$ & $-.104^{* *}$ & 14.51 & 2.30 \\
\hline 2. Local social isolation & & & $.246^{* *}$ & .060 & $.433^{* *}$ & $-.053^{*}$ & $-.146^{* *}$ & $.084^{* *}$ & $.093^{* *}$ & $-.174^{* *}$ & $-242^{* *}$ & 7.49 & 2.50 \\
\hline 3. Normlessness & & & - & $.152^{* *}$ & $.157^{* *}$ & $-.067^{*}$ & $-.095^{* *}$ & .039 & .051 & $-.140^{* *}$ & $-220^{* *}$ & 12.92 & 7.42 \\
\hline 4. Global social distrust & & & & - & .038 & -.005 & -.053 & $-.068^{*}$ & -.030 & $-.166^{* *}$ & $-.080^{*}$ & 6.97 & 1.83 \\
\hline $\begin{array}{l}\text { 5. Global social isolation } \\
\text { Values }\end{array}$ & & & & & & $-.100^{* *}$ & $-.145^{* *}$ & -.049 & $-.101^{* *}$ & $-.105^{* *}$ & $-.164^{* *}$ & 6.60 & 1.83 \\
\hline 6. Work & & & & & & & $.423^{* *}$ & $.178^{* *}$ & $.258^{* *}$ & $.114^{* *}$ & -.006 & 3.19 & 0.85 \\
\hline 7. Family & & & & & & & & $.112^{* *}$ & $.131^{* *}$ & $.080^{* *}$ & $.116^{* *}$ & 3.58 & 0.58 \\
\hline 8. Friends and acquaintances & & & & & & & & & $.556^{* *}$ & .031 & -.031 & 2.96 & 0.65 \\
\hline 9. Lieisure time & & & & & & & & & - & $.067^{*}$ & $-.077^{* *}$ & 2.94 & 0.70 \\
\hline 10. Politics & & & & & & & & & & & $.276^{* *}$ & 1.96 & 0.76 \\
\hline 11. Religion & & & & & & & & & & & - & 2.44 & 0.83 \\
\hline
\end{tabular}

It was also found that global social distrust was negatively associated with values of (1) friends and acquaintances $(p<.05)$, (2) politics $(p<.01)$ and religion $(p<.05)$. Global social isolation was negatively associated with values of (1) work $(p<.01)$, (2) family $(p<.01)$, (3) leisure time $(p<.01)$, (4) politics $(p<.01)$ and (5) religion $(p<.01)$.

Results for Estonia. Descriptive statistics and Spearman's correlation coefficients for measures of anomia and values for Estonian inhabitants are presented in Table 6. 
Jel̦ena L̦evina, Kristīne Mārtinsone, Kristiāna Klince. Relations Between Anomia and Values of the Inhabitants of the Baltic States

Table 6 Descriptive statistics and Spearman's correlation coefficients for measures of anomia and values of Estonian inhabitants

\begin{tabular}{|c|c|c|c|c|c|c|c|c|c|c|c|c|}
\hline & 1. & 3. & 4. & 5. & 6. & 7. & 8. & 9. & 10. & 11. & $M$ & $S D$ \\
\hline \multicolumn{13}{|l|}{ Anomia } \\
\hline 1. Local social distrust & $-.079^{* *}$ & $.170^{* *}$ & $.551^{* *}$ & $.115^{* *}$ & $-.083^{* *}$ & -.009 & $-.142^{* *}$ & $-084^{* *}$ & $-.153^{* *}$ & $-.112^{* *}$ & 13.53 & 2.55 \\
\hline 2. Local social isolation & & $.262^{* *}$ & $.098^{* *}$ & $.361^{* *}$ & $-.083^{* *}$ & $-.121^{* *}$ & $-.051^{*}$ & -.018 & $-.154^{* *}$ & $-.236^{* *}$ & 6.99 & 2.57 \\
\hline 3. Normlessness & & & $.173^{* *}$ & $.145^{* *}$ & $-.068^{*}$ & $-.137^{* *}$ & -.021 & .029 & $-.084^{* *}$ & $-.146^{* *}$ & 8.85 & 5.82 \\
\hline 4. Global social distrust & & & & $.178^{* *}$ & $-.068^{*}$ & $-.087^{* *}$ & $-.160^{* *}$ & $-.173^{* *}$ & $-.183^{* *}$ & $-.091^{* *}$ & 7.56 & 2.14 \\
\hline 5. Global social isolation & & & & & $-.056^{*}$ & $-.157^{* *}$ & $-.128^{* *}$ & $-.111^{* *}$ & $-241^{* *}$ & $-.219^{* *}$ & 7.29 & 1.67 \\
\hline Values & & & & & & & & & & & & \\
\hline 6. Work & & & & & & $.261^{* *}$ & $.193^{* *}$ & $.150^{* *}$ & $.117^{* *}$ & .020 & 3.26 & 0.84 \\
\hline 7. Family & & & & & & & $.197^{* *}$ & $.137^{* *}$ & $.134^{* *}$ & $.125^{* *}$ & 3.70 & 0.58 \\
\hline 8. Friends and acquaintances & & & & & & & & $.467^{* *}$ & $.138^{* *}$ & .027 & 3.13 & 0.67 \\
\hline 9. Lieisure time & & & & & & & & & $.182^{* *}$ & -.049 & 3.02 & 0.72 \\
\hline 10. Politics & & & & & & & & & & $.255^{* *}$ & 2.02 & 0.75 \\
\hline 11. Religion & & & & & & & & & & - & 1.99 & 0.85 \\
\hline
\end{tabular}

Note. $* p<.05 ; * * p<.01$

Such dimension of anomia as local social distrust was negatively associated with such values as (1) work ( $p<.01),(2)$ friends and acquaintances $(p<.01),(3)$ leisure time $(p<.01),(4)$ politics $(p<.01)$ and $(2)$ religion $(p<.01)$. Local social isolation was negatively associated with such values as $(1)$ work $(p<.01),(2)$ family $(p<.01),(3)$ friends and acquaintances $(p<.05),(4)$ politics $(p<.01)$ and (2) religion $(p<.01)$. Normlessness was negatively associated with values of (1) work $(p<.05),(2)$ family $(p<.01),(3)$ politics $(p<.01)$ and $(4)$ religion $(p<.01)$.

Global social distrust and global social isolation were negatively associated with all six values, namely (1) work $(p<.05),(2)$ family $(p<.01)$, (3) friends and acquaintances $(p<.01)$, (4) leisure time $(p<.01),(5)$ politics $(p<.01)$ and religion $(p<.01)$.

\section{Conclusions}

The present study was designed to investigate the structure of anomia and the relationship between anomia and values of the inhabitants of the Baltic state.

The first research question referred to the structure of anomia of the inhabitants of the Baltic states. In this study five components of anomia were found, namely, local social distrust, local social isolation, normlessness, global social distrust, and global social isolation. This finding is consistent with the previous studies demonstrating that anomia is multidimensional and includes among other components such components as normlessness and social isolation (L̨evina, Mārtinsone \& Kamerāde, 2015a, 2016). 
The second research question was what are relations between different dimensions of anomia and personal values of the inhabitants of the Baltic states. In the present study it was found that there are numerous relations between anomia and values of Baltic inhabitants. The importance of such value as work was negatively associated with local social isolation and normlessness. The importance of family was positively associated with local social distrust and negatively associated with local and global social isolation and normlessness. The importance of friends and acquaintances was negatively associated with local and global social distrust and global social isolation. The importance of leisure time was positively associated with normlessness and negatively associated with local and global social distrust and global social isolation. The importance of such values as politics and religion was negatively associated with all five components of anomia which were found in this study.

The third research question was what are the common, similar patterns and specific patterns of relations between dimensions of anomia and personal values of the inhabitants of Latvia, Lithuania and Estonia. The results of the correlation analysis conducted in the sample of the inhabitants of each from the Baltic states separately allow to conclude that there are thefollowing common, similar patterns of relations between anomia and values: (1) the importance of politics and religion is negatively associated with all dimensions of anomia (with one exception - there is no found the significant relation between the importance of religion and global social distrust in Latvia); (2) the importance of work and family is negatively associated with normlessness; (3) the importance of friends and acquaintances is negatively associated with global social distrust. The found common patterns regarding the negative links between the importance of politics and religion and anomia are consistent with the previous studies in which it was shown that political apathy is a substantial component of anomia (Bohenke, 2006 as mentioned in Legge, Davidov \& Schmidt, 2008) as well as that religion is an institution that might not be trustworthy for people experiencing anomic state (Carter \& Carter, 2007). The negative correlations between the evaluations of the importance of work and family and normlessness demonstrate that people who are ready to break the rules and cheat financially less appreciated work and family. The negative correlations between the evaluations of the importance offriends and acquaintances and global social distrust show that when individuals are experiencing anomia and are feeling distrust towards global organisations and unions such as UNO, NATO, EU, they can also lose the sense of significance of relationships with friends and acquaintances.

In this study some patterns of relations between dimensions of anomia and personal values were found which were specific for the inhabitants of Latvia, Lithuania or Estonia. In particular, Estonia was the only country for which it 
Jel̦ena L̦evina, Kristīne Mārtinsone, Kristiāna Klince. Relations Between Anomia and Values of the Inhabitants of the Baltic States

was found that evaluations of the importance of friends and acquaintances were negatively associated with scores in global social isolation and evaluations of importance of leisure time were negatively associated with scores in local and global social distrust. At the same time, evaluations of the importance of leisure time were positively associated with scores in local social isolation in Lithuania and with scores in normlessness in Latvia. The fact that there exist both similar and specific patterns of relations between anomia and values allows us to propose that both common and specific social, economic, political, cultural factors determine these relations.

A number of limitations need to be considered. First, taking into account, that there are no available instruments to measure multiple dimensions of anomia, in this study secondary data were used. Considering this limitation, we cannot assume that our results reflect the full picture of experiencing of anomic feeling among the inhabitants of the Baltic states. In future it is necessary to constructa new multidimensional instrument for measurement of anomia. Another limitation is that in this study only the Baltic states were explored. In future it would be valuable to investigate signs and experience of anomia and its associations with personal values in other countries.

The paper was supported by the National Research Program 5.2. "Economic Transformation, Smart Growth, Governance and Legal Framework for the State and Society for Sustainable Development - a New Approach to the Creation of a Sustainable Learning Community (EKOSOC-LV)"

\section{References}

Allport, G. W., Vernon, P. E., \& Lindzey, G. (1951). A study of values. Boston, MA: Houghton Mifflin.

Carter, E., \& Carter, M. (2007). A social psychological analysis of anomie among National Footlball League players. International Review for the Sociology of Sport, 42 (2), 243 270.

Comsa, M., \& Rusu, H. (2011). Value change in Eastern Europe: What is happening there? Studia Sociologia, 56 (1), 33-61.

Durkheim, É. (1964) [1893]. The Division of Labour in Society. NY: Free Press.

Durkheim, É. (1966) [1951]. Suicide: A Study in Sociology. NY: The Free Press.

Eṇgele, I. (2015). Indivīda vērtības. No: K. Mārtinsone, A. Miltuze (Red.), Psiholoǵija 2: Personība, grupa, sabiedrība, kultūra. Rīga: Zvaigzne ABC, 99-107. lpp.

European Values Study (EVS). (2008). Accessed January 10, 2016, http://www.europeanvaluesstudy.eu/page/survey-2008.html

Jirgena, S., \& Mārtinsone, K. (2007). Vērtību hierarhija: jauniešu salīdzinošais vērtējums 1998. un 2005. gadā. Sabiedrība un kultūra. Rakstukrājums IX. A. Medveckis (Sast.). Liepāja: LiePA, 2007, 112-119. lpp.

Karvonen, S., Young, R., West, P., \& Rahkonen, O. (2012). Value orientations among late 
modern youth - a cross-cultural study. Journal of Youth Studies, 15 (1), 33-52.

Klince, K. (2015). Latvijas iedzīvotāju vērtību un individuālās anomijas saistība. Kursa darbs. Rīga: RSU.

Konty, M. (2005). Microanomie: The cognitive foundations of the relationship between anomie and deviance. Criminology, 43 (1), 107-132.

Kopelman, R., Prottas, D., \& Tatum, L. (2004). Comparisonoffourmeasuresofvalues: Theirrelativeusefulnessingraduateeducationadvisement. North American Journal of Psychology, 6 (2), 205-218.

Lan, J. (2009). TheimpactofglobalizationonthevaluesofcontemporaryChineseyouth, Journal of Youth Studies, 12, 12-16.

Legge, S., Davidov, E., \& Schmidt, P. (2008). Social structural effects on the level and development of the individual experience of anomie in the German population .International Journal of Conflict and Violence, 2 (2) 248-267.

Levina, J., \& Martinsone, K. (2015). A revised integrative hierarchical model of anomia: Towards the construction of anomia indices. "The 14th European Congress of Psychology "Linking technology and psychology: feeding the mind, energy for life" (Milan, Italy 7-10 July 2015): Abstract book (2015): 2250. Accessed July 31, 2015, http://www.ecp2015.it/wp-content/uploads/2015/07/ECP-2015-AbstractBook_upd27jul1.pdf

Levina, J., Martinsone, K., \& Kamerade, D. (2015). Anomia as a factorpredictingsubjectivewell-being. Med. psihol. Ross., 3 (32), p. 3. Accessed October 12, 2015, http://mprj.ru.

Ļevina, J., Mārtinsone, K., \& Kamerāde, D. (2015, a). Individuālās anomijas modeḷi Latvijas populācijā. Rīgas Stradina universitāte. 2015. Gada zinātniskā konference: Tēzes (375. lpp.). Rīga: RSU.

Ļevina, J., Mārtinsone, K., \& Kamerāde, D. (2015, b). Sex and age of differences in the levels of anomia of Latvian inhabitans. Society, Integration, Education. Proceedings of the International Scientific Conference 3, 567-576.

Ļevina, J., Mārtinsone, K., \& Kamerāde, D. (2016). A model of anomia in the Baltic states. Submitted for publication in The Interdisciplinary Social Sciences Collection.

Ļevina, J., Mārtinsone, K., Mihailova, S., \& Gintere, I. (2015). Characteristics of personal value-meaning systems of Latvian youths in 1998, 2005, 2010 and 2015: A comparative study. Society, Integration, Education. Proceedings of the International Scientific Conference 3, 577-587.

Likitapiwat, T., Sereetrakul, W., \& Wichadee, S. (2015). Examining materialistic values of university students in Thailand. International Journal of Psychological Research, 8 (1), 109-118.

Lūse, D. (2001). Individuālisma un kolektīvisma vērtību orientācijas Latvijas jauniešu vidū. IT laikmets: jaunatne un sociālās izmainas. Rīga: FSI, VJIC, 249-255. lpp.

Maercker, A., Zhang, X. C., Gao, Z., Kochetkov, Y., Lu, S., Sang, Z., Yang, S., Schneider, S., \& Margraf, J. (2015). Personal value orientations as mediated predictors of mental health: A three-culture study of Chinese, Russian, and German university students. International Journal of Clinical and Health Psychology, 15, 8-17.

Matsumoto, D. (Ed.) (2009). The Cambridge dictionary of psychology. Cambridge: Cambridge University Press, p. 40.

Meral, C. (2000). Change in value orientations of Turkish youth from 1989 to 1995. Journal of Psychology, 134 (3), 297-305.

Orru, M. (1987). Anomie: History and meanings. Boston, MA: George Allen \& Unwin. 
Jel̦ena L̦evina, Kristīne Mārtinsone, Kristiāna Klince. Relations Between Anomia and Values of the Inhabitants of the Baltic States

Rokeach, M. (1973). The nature of human values. New York: Free Press.

Salikhova, N. (2015). The comparison of substantial and dynamic parameters personal valuemeaning systems of American and Russian university students. Review of European Studies, 7 (4), 117-123.

Schwartz, S. H. (1992). Universals in the content and structure of values: Theory and empirical tests in 20 countries. In M. Zanna (Ed.), Advances in experimental social psychology. San Diego, CA: Academic Press, pp. 1-65.

Schwartz, S. H. (2006). Basic human values: An overview basic human values: Theory, methods, and applications introduction to the values theory. Revue Françaisede Sociologie, 47 (4), 249-288.

Schwartz, S. H., \& Bardi, A. (1997). Influences of adaptation to communist rule on value priorities in Eastern Europe. Political Psychology, 18, 385-410.

Spranger, E. (1928). Types of men: The psychology and ethics of personality. Halle, Germany: Max Niemeyer.

Srole, L. (1956). Social integration and certain corollaries: An exploratory study. American Sociological Review, 21 (6), 709-716.

Swader, C. (2011). Linkingnormlessnessandvaluechangeinthe Post-communistworld. Studia Sociologia, 56 (1), 63-94.

Tilburg, W., \& Igou, E. (2011). On the meaningfulness of existence: When life salience boosts adherence to worldviews. European Journal of Social Psychology, 41, 740-750. 